\title{
I-Pillars of Noise Barriers Made of Prestressed Steel Fiber Concrete and Prestressed Concrete with Footings Length of $800 \mathrm{~mm}$
}

\author{
Jindřich Čech ${ }^{1, *}$, Petr Tej ${ }^{1}$, Jiří Kolísko ${ }^{1}$, Petr Pokorný ${ }^{1}$ and Alena Kohoutková ${ }^{2}$ \\ ${ }^{1}$ Klokner Institute, Czech Technical University in Prague, Czech Republic \\ ${ }^{2}$ Faculty of Civil Engineering, Czech Technical University in Prague, Czech Republic \\ *Corresponding author
}

\begin{abstract}
This researche examines flexural behavior of I-shaped pillars in noise barriers made of prestressed concrete and prestressed steel fiber reinforced concrete under loading corresponding to their actual loading - effect of wind on the panels. Three specimens of I-pillars were tested in laboratory and calculated by numerical analysis. The results of this research were compared and discussed in this paper.
\end{abstract}

Keywords-pillars of noise barriers; steel fiber reinforced concrete; cracks

\section{INTRODUCTION}

Pillars which serve as supporting elements in noise barriers had been made from prestressed concrete and prestressed steel fiber reinforced concrete. This pillars had I-shaped cross sections with a height of $350 \mathrm{~mm}$ and a width of $250 \mathrm{~mm}$ and with a length of $2250 \mathrm{~mm}$ (see Figure 1). The pillars were supported by $800 \mathrm{~mm}$ long base with a cross-section of $650 *$ $750 \mathrm{~mm}$ (larger dimension parallel to the direction of the applied load). Different types of concrete had been used: C30/37 for the base and C55/67 for the prestressed concrete and fiber reinforced concrete pillars. The material properties were determined using associated loading tests [1]. The material tests were carried out using a four-point bending test on beams to determine the fracture energy, and on the cubes and cylinders to determine compressive strength, the splitting tensile strength and the modulus of elasticity of the specimen.

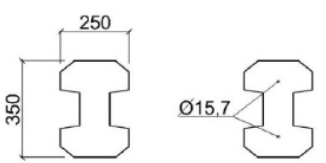

a)

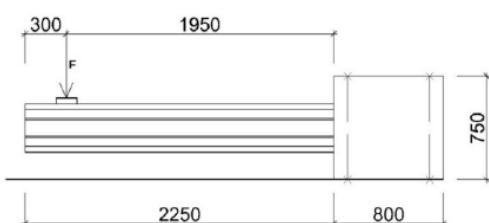

b)

c)
FIGURE I. SHAPE OF CROSS-SECTION AND REINFORCEMENT OF COLUMNS: a) THE DIMENSIONS AND SHAPE OF THE CROSSSECTION, b) REINFORCEMENT OF PRESTRESSED COLUMNS, c) TEST ARRANGEMENT

\section{EXPERIMENTAL PROGRAM}

Concrete. Associated tests on the material of the columns were carried out in order to determine the real material properties. A four-point bending test was performed on the beams to determine the fracture energy, and on the cubes and cylinders to determine the compressive strength, the splitting tensile strength and the modulus of elasticity.

Reinforcement. The prestressing reinforcement was formed with steel tendons with a profile of $15.7 \mathrm{~mm}$, and 140 $\mathrm{mm}^{2}$ cross-sectional area marked Y $1770 \mathrm{~S} 7$ - 15.7 -with a yield strength of $1570 \mathrm{MPa}$, an ultimate strength of $1770 \mathrm{MPa}$ and a modulus of elasticity of $195 \mathrm{GPa}$. The dispersed reinforcement in the steel fiber reinforced concrete columns was formed with Fibrex fibers. The amount of fibers was 40 $\mathrm{kg} / \mathrm{m}^{3}$ of concrete, fiber length of $25 \mathrm{~mm}$, with hooks at the ends. The reinforcement of the footings was formed with longitudinal reinforcement bars with a profile of $10 \mathrm{~mm}$ and transverse closed stirrups also with a profile of $10 \mathrm{~mm}$ made of steel B500B.

\section{NONLINEAR FE ANALYSIS}

The FEA model was created using Atena Engineering 3D. The custom column was created as a rod macroelement with a constant cross-section shape I with chamfered corners and lengths of $3050 \mathrm{~mm}$. The footings were created as macroelement rectangular prisms with a hole for insertion of the column. The load column was already defined in the centroid of a distribution plate which was $1950 \mathrm{~mm}$ from restraint of column to footing. The plate had dimensions of $150 \mathrm{~mm} * 150 \mathrm{~mm} * 30 \mathrm{~mm}$, and its outer side consisted of four triangular faces that had a common point at the centroid of the square side of the plate (another two points were always the two peaks of the square side of the plate). The centroid of this side of the plate was defined with a $0.1 \mathrm{~mm}$ displacement perpendicular to the plate (i.e., transverse to the column as in the experiment) at each step of gradual loading. In order to fix the whole structure (column + footing) three additional auxiliary macroelements were modeled, in addition to the standard support [2]. These were: a plate (simulating the base grid in the experiment) adjacent to the bottom surface of the footing, and the presser bar macroelements placed across the top footing area, about $150 \mathrm{~mm}$ from the edges of the footing (simulating U-profiles with snapped threaded rods attached to the base grid in the experiment). Individual supporting auxiliary macroelements were placed on the averted side of the footing with supports preventing more than six degrees of freedom. 
The material of the columns was selected from the catalog of the program Atena Engineering 3D concrete C55/67 and its properties were modified according to the test results of material properties in the experiment [3]. The compressive strength and the tensile strength, the elastic modulus and the fracture energy were modified. As compressive strength was used, its strength was calculated experimentally on the concrete cylinders. In addition, for the modeling of steel fiber reinforced concrete, the coefficient reduction of compressive strength was modified (due to cracks resulting from the value of plain concrete $(0.2)$ ) to the value of steel fiber reinforced concrete (1.0) [4]. At the same ratio as that between the fracture energy of concrete and steel fiber reinforced concrete, there was also an increased item called Critical Compressive Displacement Wd. With the steel fiber reinforced concrete thus defined, a running calculation was made of a beam with dimensions of $150 \mathrm{~mm} * 150 \mathrm{~mm} * 600 \mathrm{~mm}$, loaded for fourpoint bending, in which was drawn a stress-strain diagram of the material from the specified monitors for strain and stress on the bottom fiber at the center of the span of the beam. The stress-strain diagram was then used to define the steel fiber reinforced concrete columns of the Atena material items known as Nonlinear Cementitious 2 User. The material for the footing was chosen from the catalog of the C30/37 concrete program with mean values of material properties [5]. As mild reinforcement for the concrete columns, reinforcement was selected with a bilinear stress-strain diagram of hardening, with mean values of stress and strain [6]. Cables for prestressing the reinforcement were chosen with a bi-linear stress-strain diagram of hardening, with mean values of stress and strain. For the material of the load distributing plate and the auxiliary support macroelements 3D isotropic elastic material was chosen with the material properties $\mathrm{E}=210 \mathrm{GPa}$ and $v=0.3$.

For the creation of load-deflection curves in the FE analysis, monitoring points to record the necessary data were defined on the construction. In addition to the monitoring point of the displacement at the point of a defined shift, the monitoring point of applied force corresponding to the shift was defined in the same place. The monitoring point for the pulling of the prestressing reinforcement inside the column was also defined, for comparison purposes within the experiment.

As already mentioned, each prestressing cable was set in the factory with a prestressing stress of $1375 \mathrm{MPa}$. The FEA model was prestressed according to this stress factor, reduced by possible short-term losses (slippage, relaxation of prestressing reinforcement, elastic deformation of the concrete), and loss due to creep and shrinkage of the concrete in between prestressing in the factory and testing in the laboratory [7]. Because each column set contains footings of different lengths, the prestressing cables also had to be of different lengths, which accounted for differences, especially in losses due to slippage. This had a consequent effect on the calculation of loss by elastic deformation of the concrete, in which all other short-term loss counts [8].

For calculation a mesh of tetrahedral finite elements of size $75 \mathrm{~mm}$ was generated. For the calculation of a reinforced concrete column 500 steps were already defined for a total deflection of $50 \mathrm{~mm}(500 * 0.1 \mathrm{~mm})$; for calculations of the prestressed columns 695 steps were already defined, namely 10 steps with a coefficient of 0.1 for prestressing, and 685 steps for a total deflection of $68.5 \mathrm{~mm}(685 * 0.1 \mathrm{~mm})$. To save calculation time, the calculation was often terminated earlier, about 30 steps after the maximum application of forces. For calculations of FEA models columns the Newton-Rapson computing system was used, with 40 iterations in each step. [9]

\section{RESUlts}

Experiment results are shown at Figure 2 and Tab. 1. The load-deflection diagrams with the deflection at a distance of $1.95 \mathrm{~m}$ from the restraint were modified due to imperfect mounting of footing to the grid and the resulting footings rotation in the clamping. With this modification the rotation and the resulting larger deflections were eliminated or reduced. The experiment results were compared with the results of nonlinear FE analysis. Higher values of both analyzed columns showed the prestressed steel fiber concrete column.

TABLE I. COMPARISON OF FE ANALYSIS AND EXPERIMENTS FOR PRESTRESSED CONCRETE COLUMN AND PRESTRESSED SFRC COLUMN

\begin{tabular}{|c|c|c|c|c|}
\hline & \multicolumn{2}{|c|}{ Experimental values } & \multicolumn{2}{|c|}{ Value from FEM analysis } \\
\hline & $\begin{array}{c}\text { Prestressed concrete } \\
\text { column }\end{array}$ & $\begin{array}{c}\text { Prestressed SFRC } \\
\text { column }\end{array}$ & $\begin{array}{c}\text { Prestressed concrete } \\
\text { column }\end{array}$ & $\begin{array}{c}\text { Prestressed SFRC } \\
\text { column }\end{array}$ \\
\hline \multirow{3}{*}{ The maximal force $(\mathrm{kN})$} & 42.00 & 43.50 & \multirow{3}{*}{43.77} & \multirow{3}{*}{44.04} \\
\hline & 42.90 & 43.40 & & \\
\hline & 40.20 & 43.50 & & \\
\hline \multirow{3}{*}{$\begin{array}{l}\text { Deflection at maximum force at the } \\
\text { place of load }(\mathrm{mm})\end{array}$} & 45.01 & 53.97 & \multirow{3}{*}{41.60} & \multirow{3}{*}{57.30} \\
\hline & 46.17 & 48.90 & & \\
\hline & 43.11 & 53.27 & & \\
\hline \multirow{3}{*}{$\begin{array}{l}\text { Force at which the crack width } \\
\text { exceeds } 0.2 \mathrm{~mm}(\mathrm{kN})\end{array}$} & 30.00 & 34.00 & \multirow{3}{*}{32.85} & \multirow{3}{*}{33.68} \\
\hline & 32.50 & 33.00 & & \\
\hline & 28.00 & 34.00 & & \\
\hline
\end{tabular}




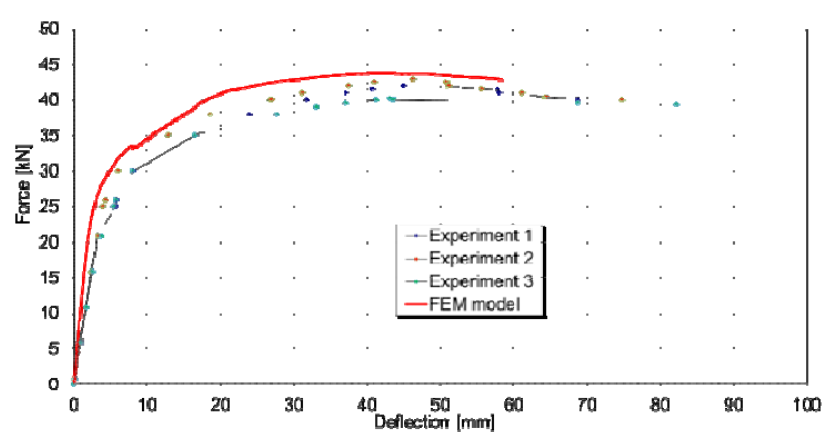

a)

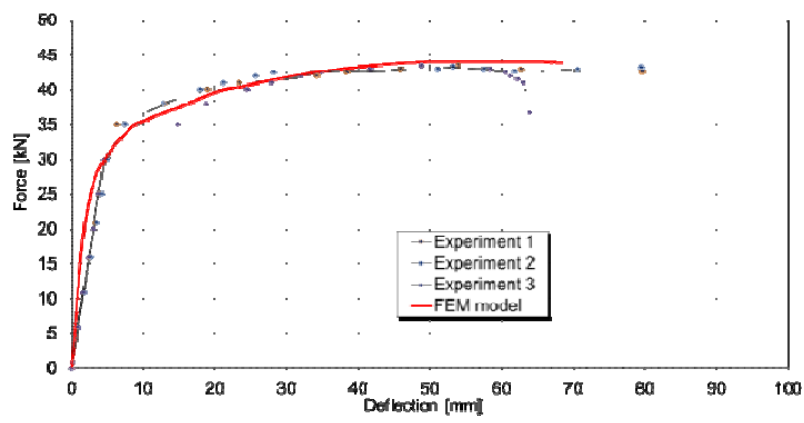

b)

FIGURE II. LOAD-DEFLECTION GRAPH IN PLACE UNDER LOAD -a) PRESTRESSED CONCRETE COLUMN; b) PRESTRESSED SFRC COLUMN

\section{CONCLUSIONS}

According to the assumption the best values of both analyzed materials showed the prestressed steel fiber concrete. The monitored parameters of pillars were the maximum load capacity and load capacity at crack width of $0.2 \mathrm{~mm}$. Also, as expected, the worse values came in both criteria for prestressed concrete pillar.

\section{ACKNOWLEDGMENTS}

This research is supported by grant GACR $104 / 15$ 22670S Experimental and numerical analysis of bond behavior between steel reinforcement and ultra-high performance concrete.

\section{REFERENCES}

[1] I. Broukalová, A. Kohoutková, Influence of the Rate of Loading on Determination of Material Characteristics, Proceedings of $6^{\text {th }}$ CCC Congress in Mariánské Lázně 2010. Concrete Structures for Challenging Times, ČBS, Praha (2010) 402-406.

[2] P. Marti, Modelling of Structural Conrete, fip Symposium „Keep Concrete Attractive“", Budapest. (2005)

[3] J. Krátký, H. Hanzlová, A. Kohoutková, J. Vašková, J. Vodička, Experimenty a analýza chování konstrukčního vláknobetonu, ČVUT, Praha. (2011)

[4] S.K. Padmarajaiah, A. Ramaswamy, Flexural strength predictions of steel fiber reinforced high-strength concrete in fully/partially prestressed beam specimen, Cement and Concrete Composites 26 (2004) 275 - 290.

[5] ČSN EN 1992-1-1. Eurocode 2: Navrhování betonových konstrukcí Cást 1-1: Obecná pravidla a pravidla pro pozemní stavby, Praha, ČNI, 2005 .

[6] Y. Othani, W. F. Chen, Multiple Hardening Plasticity for Concrete Materials, Journal of the EDM ASCE. (1988)
[7] J. Vodička, D. Spůra, Creep and Shrinkage of Structural Fiber Concretes, Beton TKS 2 (2010) 96-99.

[8] H. Liu, T. Xiang, R. Zhao, Research on non-linear structural behaviors of prestressed concrete beams made of high strength and steel fiber reinforced concretes, Construction and Building Materials 23 (2009) 85 -95 .

[9] A. Kohoutková, P. Procházka, J. Vodička, Coupled Modeling of Fiber Reinforced Concrete for Splitting Tensile Strength, Fibre Reinforced Materials, Singapore (2010) 183-190. 